Please refer to the definitive version of this article when citing:

Cohen, E., Cohen, S.A. \& King, V.T. (2017). The global permutations of the Western publication regime. Current Issues in Tourism, DOI: 10.1080/13683500.2016.1272556

\title{
The Global Permutations of the Western Publication Regime
}

\begin{abstract}
This article introduces the concept of the 'publication regime' into the current discourse on academia. This allows for a much deeper understanding of how publishing conglomerates and appointment and promotion procedures in Western universities are increasingly interlocked. It then turns to the global permutations of that regime as it is currently disseminated to other parts of the world. Using empirical examples drawn primarily from the field of tourism studies, we examine the problems engendered by the introduction of the regime's appointment and promotion procedures of early career academic staff in universities in the emerging world regions. We specify the auxiliary mechanisms intended to ameliorate these problems, and draw attention to the neocolonial implications of the disciplining process which these mechanisms are introducing into the academic life of the universities in the emerging regions. We argue that, as the Western publication regime is becoming increasingly globalized, local intellectual voices tend to be silenced by the regime's growing hegemony, and, call for the integration of non-Western perspectives into the framework of the publication regime.
\end{abstract}

Keywords: publication regime, metrification, academic rankings, promotion procedures, disciplining, Eurocentrism, emerging world regions, neo-colonialism

\section{Introduction}

A 'publication regime', which is based on the interlocking between the procedures regulating scientific publication, adopted by the major publishing companies, and the procedures implemented by university authorities for the appointment and promotion of academic staff, has appeared in the contemporary 'West', a term we use here to include Europe, North America, Australia and New Zealand. However, though that regime has been much criticized in the West, in for instance the fields of management and marketing (Butler and Spoelstra 2014; Hussain 2013; 
Tadajewski 2016), at the same time it is undergoing rapid dissemination and being increasingly and mostly uncritically adopted by academic institutions in emerging world regions, namely the regions of Asia, Latin America, Africa, the Middle East, Oceania and the Caribbean, presently undergoing globalization and emerging on the world scene. In this article we examine five interrelated issues, which are raised by the emergence and dissemination of the publication regime: 1) the regulation of the publication process; 2) the metrification of the nomination and promotion criteria deployed by Western universities; 3) the adoption and permutations of the publication regime by universities in the emerging regions of the world; 4) the disciplining of early career academic staff in the emerging regions to prepare them for participation in the regime; and 5) the neo-colonial implications of the disciplining process. We discuss the publication regime in general terms, but our specific examples are taken from the field of tourism studies, with which we are most familiar and which is a relatively new and rapidly expanding multidisciplinary academic field, particularly in emerging world regions.

The academic publication process can be seen as a regulated 'flow' of papers from submission to publication, and from there to the readership. This information flow is regulated and normalized by formal procedures, which pass some submissions ('accepted'), but causes friction ('revise'), or even block others ('rejected').

With growing regulation, the writing of articles became disciplined (in Foucault's [1977] sense of disciplining as a modern technology of power), just as in the army the body is disciplined. The disciplining process has been examined in several academic fields (Abrahamsen 2000, Foote and Frank 1999, Knights and Collinson 1987), especially in education (Bill 2004, Dunn-Kenney 2013, Grant 1997, Middleton 2005, Niesche 2013), but has not yet been applied to the study of academic publishing or promotions in a globalizing world. 
The structure of article submissions became formalized, as, for example, in the domain of tourism studies: abstract, keywords, introduction, aims, literature review/theoretical approach, methodology, results, discussion, conclusion, limitations, future research, acknowledgements, references. Adherence to such demands facilitated the movement of a submission through the publication process, irrespective of the scientific quality of its results. The processing of submissions is handled by the editors of particular journals. The editors are mostly Western-trained academics; thus, the editors of the leading tourism journals, such as Annals of Tourism Research, Tourism Management, Journal of Tourism Research and Journal of Sustainable Tourism are all Western-trained and based in Western universities. Editors occupy a pivotal position between the publishers and the academic community. Upon receiving a submission, the editor of a journal decides either to reject it outright ('desk rejection') or to send it out, often via a sub-editor, to several referees on whose advice he or she makes a formal editorial decision. The decision is analogous to that of a consular official in an embodied mobilities regime (Glick Schiller and Salazar 2013) to admit or reject a visa applicant, or of a border official to grant entry.

\section{The Regulation of the Publication Process}

The emergence of the academic publication regime was facilitated on the one hand by a structural transition in the publication industry from a multiplicity of publishers of individual journals, to their concentration in a handful of giant Western-based publishing companies, and on the other by the introduction of quantified measurements, of scientific production in academic promotion procedures, referred to here as 'metrification'. 
Each of the major publishing houses, such as Taylor and Francis, Elsevier, Emerald, Cognizant Communication Corporation, Springer, Inderscience or SAGE, publishes hundreds of journals in a wide range of fields, predominantly in the English language. In the field of tourism, in 2015 four publishing houses, Taylor and Francis, Elsevier, Emerald and Cognizant Communication Corporation, published 65 tourism journals, including the great majority of top-ranking publications, among the more than 300 tourism, hospitality and events journals published worldwide (Bob McKercher, personal communication, 6 August, 2015).

Economies of scale enabled the publishers of large numbers of journals to introduce uniform, formalized web-based software for the submission, review and evaluation of papers, cutting across the gamut of disciplines, such as ScholarOne Manuscripts or EVISE, though editors of some individual journals have also added further submission instructions. However, recognizing the difficulties authors face in trying meticulously to format their submissions, some journals recently reduced the stringency of their requirements; thus, Elsevier introduced a 'Your Paper Your Way' format, to facilitate new submissions.

\section{The Metrification of Scientific Production}

\section{Ranking Guides}

Journal ranking guides, such as the UK's Association of Business Schools' (ABS) Academic Journal Guide and the Australian Business Deans Council (ABDC) Journal Quality List, became an influential factor in the emergent process of metrification of academic achievements and in national research assessment exercises, such as the Research Excellence Framework (REF) in the United Kingdom, or the Excellence in Research for Australia (ERA), both of which were 
introduced in wake of the expansion of neo-liberal policies into the academic sphere (Hall 2013). English is the dominant language in the ranking guides. In the ranking of tourism-related journals by the 2014 SJR list (Journal and Country Rank), compiled by SCImago, English-language journals dominate (www.scimagojr.com/journalrank.php?category=1409): all top ten tourism journals are published in English, by major Western publishing houses, a telling indication of the virtual monopoly of English in scientific production (Hall 2013).

The 2015 ABS journal guide for business and management studies, based on a combination of journal metrics, perceptions of editors, scholarly associations, a scientific committee, and 'expert peers', ranks journals on a scale from 1 (lowest) to $4 *$, with $4 *$ denoting 'Journals of Distinction'. No tourism journals are rated as 4*; but three, are rated 4: Annals of Tourism Research, Tourism Management, and Journal of Travel Research. One tourism journal is rated 3, the Journal of Sustainable Tourism. Ranked on lower levels is a 'long tail of weaker [tourism] journals' (Airey, Tribe, Benckendorff and Xiao 2015). Some of the latter originated in emerging world regions: for instance Tourism Recreation Research in India (ABS ranked 2) and Anatolia: an International Journal of Tourism and Hospitality Research, in Turkey (ABS ranked 1). Both of these have been recently acquired by Taylor and Francis.

The Australian ABDC Journal Quality List, created originally to help assess publication quality in preparation for the national research assessment exercise, ranks journals on a scale from C (lowest) to $\mathrm{A}^{*}$. That scale is presently widely used in academic procedures, particularly by business schools, which often include tourism departments.

The Metrification of Appointment and Promotion Procedures 
The appointment and promotion procedures of Western universities have become in recent years ever more tightly based on quantified criteria. As with the extension of neo-liberal policies to higher education the balance of power and influence in many universities shifted from the academic staff to the administrators, appointment and promotion procedures were increasingly formalized, and extrinsic quantitative measurements of scientific achievement prioritized over the substantive evaluation of the quality of a candidate's work. Concomitantly, regularized systems of monitoring and auditing, by which individual academics or departments became subject to evaluation and ranked in a national system of research assessment, were developed in such Anglophone countries as Australia and New Zealand, and carried to a bureaucratic extreme in the UK. The emergence of global university rankings, such as the QS University Rankings or the Times Higher Education World University Rankings, has increased competition between universities, and further exacerbated the trend towards the quantification of achievements.

Appointments and promotions in Western universities became increasingly based on articles published in internationally refereed and ranked journals, while edited books and chapters in books were then devalued or invisible in promotion procedures. Early career academic staff are typically required to publish, or at least submit, a certain number of publications per year, in high-ranking journals in a particular ranking system (e.g. ABS 4, or A*or A in the ABDC). They are instructed on where to publish in order to enhance their prospects for promotion and to contribute to their school/department's international esteem and the global ranking of their university. Some university departments even hand academic staff lists of target journals in particular disciplines; publications outside those lists do not support promotion.

With growing reliance on formalized university promotion procedures, ever more precise metrified measurements of academic achievement came into prominence. The two principal ones are the 
impact factor (IF) and the citation frequency of a candidate's published work. These journal metrics have been widely adopted by Western universities as a principal indicator of scientific achievements, and hence came to play a crucial role in academic appointments and promotion decisions (Hall and Page 2015, Perdue 2015).

\section{Criticism of the Metrification of Scientific Achievement for Academic Promotion}

The growing dependence of Western academic and governmental institutions on various metrics, and particularly the IF, for the evaluation of scientific achievements, has provoked considerable controversy in the Western academia. It was criticized for technical deficiencies (Vanclay 2012, Varma 2015), and detrimental consequences on the direction of scientific research and on early career development. Espeland and Sauder (2007: 2) pointed out that such measurements are 'reactive'; hence, 'they elicit responses from people who intervene in the objects they measure'. Critics have consequently argued that actors 'play to the test,' and that they focus on indicators rather than on the qualities that the measurements are designed to evaluate (Espeland \& Sauder 2007: 2).

It has been argued that the quest for a higher IF ranking might induce editors to prefer 'citable', mainstream papers to more specialized ones (Poria, Schwartz and Uysal 2015), and shape scholars' decisions on the kinds of topics and issues they study, and on their choice of methodology and publication venues (Smeyers and Burbules 2011). The perceived centrality of IF might thus deflect the focus of scientific work from what to publish to where to publish (cf. Perdue 2015), and to motivate researchers to pursue mainstream topics of research, believed to be suitable for publication in high IF journals (Poria et al. 2015), rather than tackling more innovative, exploratory 
topics, which are more suitable for publication in lower-IF outlets (McKercher 2015). However, even as the domination of metrified indexes in nomination and promotion procedures was increasingly criticized in the West, they became progressively adopted by the universities in the world's emerging regions, as will be shown below.

\section{The Dissemination of the Western Publication Regime to Emerging Regions}

The academic publication regime is culturally, institutionally and linguistically rooted in the West, and bears a distinct Western, or Eurocentric, or even Anglocentric character. The regime was introduced in the West in the contemporary period under the pressures of a neo-liberal ideology, which has expanded from the traditional domain of the economy to embrace other, previously relatively autonomous domains such as health, art, religion and academia. But as this neo-liberal orientation increasingly spread to the emerging world regions (Poocharoen and Brillantes 2013), it engendered a process of 'university restructuring [which] is taking a similar path in a variety of countries with different social, political and economic regimes' (Torres and Schugurensky 2002: 429). Under the impact of the forces of globalization, and the growing hegemony of neo-liberalism in many countries, the leadership of universities around the world has reconsidered their traditional missions in favor of concerns about excellence, efficiency, expenditures and rates of return, and the enhancement of their global rankings. As part of this reorientation, the universities' leadership adopted the requirements of the publication regime, despite its Eurocentrism, and a growing criticism of its metric indicators and ranking methods in Western academia. Consequently, a major transition took place in the universities in the emerging regions, from internal traditions of 
conducting academic nomination and promotion to formalized procedures based on external indicators of academic achievement.

Promotions in universities in emerging regions used to be primarily based on bureaucratic criteria of seniority, patron-client ties, paternalistic relations between senior and early career members of staff, or even cronyism, while publications did not necessarily play a crucial role in such decisions. Publication was often left to the discretion of individual members of staff, who might have written learned discourses according to prevailing intellectual genres. These were mostly written in the national language and locally published. This mode of publication was particularly widespread in Latin America.

While customary arrangements and personal connections still play a role in promotions in the emerging regions, in recent years they have been in many universities formally replaced by scientific productivity as a leading criterion for academic advancement. This, in turn, has led to pressures on early career staff to publish in order to gain promotion. Many universities in the emerging regions at first started local journals. For example, in the field of tourism new journals emerged, such as Tourism Tribune in China, Tourism Development Journal and South Asian Journal of Tourism and Heritage in India, ASEAN Journal of Hospitality and Tourism in Indonesia, Asia-Pacific Journal of Innovation in Hospitality and Tourism in Malaysia, South African Journal of Hospitality in South Africa, Anatolia in Turkey and Iranian Journal of Tourism and Hospitality in Iran, Estudios y perspectivas de tourismo in Argentina, Revista brasiliera de pesquisas en turismo in Brazil, and Gestionturistica in Chile, and, most recently, the Asian Journal of Tourism Research in Thailand. Though some of these journals copied the Western procedure of refereeing submissions, the quality of their publications was often problematic and their impact on the field generally low; they were mostly not included in the major international journal indexes 
and not much cited. The few tourism journals from the emerging regions, which gained wider recognition, such as Anatolia and Tourism Recreation Research, were eventually acquired by multinational Western publishing houses and thereby incorporated into the Western publication regime.

The universities in the emerging regions, with some notable exceptions, have generally occupied low positions in universities rankings. The aim of the universities' leadership to enhance their rankings became a major driver to raise the visibility of the research of their academic staff. Leading universities in the emerging regions have therefore begun to pressure their staff to publish in high-ranking internationally recognized journals, or at least in periodicals listed in major indexes, such as Scopus, SCI (Science Citation Index) or SSCI (Social Science Citation Index). Publications in such journals became in many universities the principal criterion in academic appointment and promotion procedures. However, the rigor and specificity of demands regarding publications, and the weight accorded to them, vary widely between countries in the emerging regions, and specific institutions of higher learning within each of them, as can be seen from the following examples, taken from different geographical regions, which we have collated from the available information published by universities, secondary literature, the Internet or through personal contacts.

In Chinese universities publications play a crucial role in academic advancement and recompensation. González, Liu and Shu (2012: 1) report that '[t]here is great competition for funds and status [between universities], which is why Chinese universities are very interested in quality assessment.' Such assessments impact directly on faculty salaries, which 'include two components: the base salary, which is a fixed amount of money... and a variable amount of money determined by an annual performance review' (González et al. 2012: 7). These authors assert that 
this arrangement causes 'a great deal of anxiety and insecurity' among faculty members, who, 'are under stress to come up with large numbers of publications year after year.' Therefore 'recent scandals involving plagiarism and fabrication of data must be understood in the context of a ruthless "publish or perish" system that punishes harshly those who do not meet its quantity standards' (González et al. 2012: 7).

González et al. (2012: 8) offer as an example the specific requirements at one Chinese university:

[E]ach published paper must be at least 3,000 words long in certain types of journals and at least 5,000 words long in others. Shorter pieces, such as brief articles, book reviews or paper abstracts do not count. Only publications in which the candidate is first or a corresponding author are considered...Book chapters and other such publications are acceptable if they appear in a volume with either an ISBN or an ISSN number, but weigh little...Journals are classified into three categories: top, core, and common. Very detailed rules must be followed with respect to the number of publications required in each class of journal for each of the professorial ranks and disciplines.

Shao and Shen (2011) assert that, in China, 'the academic level of a university...is evaluated mainly on the number of SCI papers, EI [Ei compendex, an engineering literature database] papers, ISTP [International Society of Thesis Publication journals index] papers and the research grants it receives. ... Only journals which are...indexed by SCI or EI are regarded as top journals.' On the individual level, 'the monetary reward [for publishing in those journals] is used [as a criterion] for job promotion. This practice... has caused the outflow of many high-quality papers to SCI or EI journals. Because most SCI journals are in English... only a few journals from China are sourced.' Members of tourism departments in Chinese universities seem to publish predominantly in seven tourism-related journals listed in CSSCI (Chinese Social Science Citation Index); while Chinese 
language publications are admissible for appointment and promotion, the universities attach higher significance to publications in SSCI, which are generally in English (Xuan Zhu, personal communication, 17 August 2015).

An Asian university with a strong tourism school has recently introduced a most intricate, finely tuned scheme for the evaluation of its academic staff. The scheme distinguishes between criteria for the appraisal and for contract renewal of members of staff on four grades of the academic hierarchy. Regarding publications, the scheme lists the following criteria:

Professor: Appraisal - a minimum of one grade B or above refereed article per year in the university's list of threshold journals for staff performance assessment. Contract renewal - a minimum of two grade A refereed articles in the listed journals.

Associate Professor: Appraisal - same as above. Contract renewal - a minimum of two grade B or above refereed articles per year in the listed journals.

Assistant Professor: Appraisal - same as above. Contract renewal - a minimum of one grade A or above and one grade B or above refereed articles per year in listed journals.

Lecturer: Appraisal - a minimum of one grade B or above refereed article in the listed journals. Contract renewal - a minimum of one grade B or above refereed article published per year.

The scheme also specifies the rules regarding credit sharing on joint publications as follows:

Co-authored papers will have the following weights irrespective of the journal grades:

Authorships| 1st author 2nd author 3rd author 4th author or higher

Single author 1.00

2 authors $\quad 0.6 \quad 0.4$

$\begin{array}{llll}3 \text { authors } & 0.5 & 0.3 & 0.2\end{array}$

$\begin{array}{lllll}\mathrm{n} \text { authors } & 0.5 & 0.3 & 0.15 & 0.05 /(\mathrm{n}-3)\end{array}$

While these rules are applied on the university-wide level, the tourism school of the university has evolved its own list of A-D graded journals in the field of tourism studies (all in English), which are used for its staff performance assessment. Publications outside this list do not count in such assessments. 
India has introduced a somewhat less demanding, country-wide system in national universities. Its Universities Grant Commission (2010) has proposed an API (Academic Performance Indicators) points-scale for academic grades ranging from Assistant Professor to Professor. In the category 'Research and Academic Contribution' research papers in both 'refereed' and 'non-refereed but recognized and reputable' journals count, but more points (15 per publication) are allotted to the former than to the latter (10 per publication). But the API also recognizes 'text or reference books' which have passed peer review (50 points per book) and some other types of publications.

At Singapore's Nanyang Technological University candidates for tenure are expected to have at least four publications in 'top tier/A journals.' In the Tourism and Hospitality Management program within the Nanyang Business School these are specified as Annals of Tourism Research, Tourism Management and Journal of Travel Research. However, even these leading tourism journals are not very well regarded at the university level compared with those in other business studies disciplines (Joan Henderson, personal communication 8 August 2015).

In Malaysia, the managerial approach to higher education has intensified during the last decade. The government introduced a New Remuneration Scheme (NRS) in 1992 for its public sector, including the state-funded universities, intended to encourage a performance-based culture (Morris, Yaacob and Wood, 2004) and identified five research-based universities, all of which appear in the top 500 QS-rankings, to be given increased autonomy from state-funding. All five institutions have adopted promotion procedures which emphasize research outputs and publications (Ahmad, Morshidi and Dahlan, 2011). Three of them have tourism studies programs, at the Masters and Doctoral level. 
We have detailed information on one Malaysian university's institutional expectations for staff performance and promotion (referred to as the Standard Academic Performance Target [SAPT]): SAPT includes a point-scale for performance targets, according to academic rank; the publication requirement for consideration for promotion specifies refereed full-length articles in top-tiered ISIranked journals. A points system for consideration for promotion has been introduced for ISIrefereed articles (specified at Faculty and Department level), as well as chapters in books. This ranges from a minimum total of 50 points for Professor A, 40 for Professor B, 30 for Professor A, 15 for Associate Professor, 8 for Senior Lecturer to 5 for Lecturer. Other criteria considered are books published with internationally recognized academic publishers; supervision of research students brought to completion; research funding; consultancies and related activities; and then finally teaching quality and administration (Shanthi Thambiah, personal communication, 7 August, 2015).

In Thailand, the importance of international rankings has been inserted into every level of university life (Lao 2015). The national authorities in 2009 designated nine academic institutions as 'research universities', intended to achieve 'world class' status. Though the Office of Civil Service Commission (OCSC), which sets the criteria for academic promotion, still prioritizes teaching, it pays increasing attention to publications in international outlets in promotions to associate and full professorships (Lao 2015). The OCSC does not provide further specifications, but in Thai research universities, academic staff members are required to publish in Scopus-listed journals as part of their promotion requirements.

The tendency to relate promotion prospects to ISI- and Scopus-listed journals has been generated in no small part by the creation in 2001 of the Thai-Journal Citation Index Center (TCI), which in 2008 expanded its coverage to the humanities and social sciences (Sombatsompop et al. 201). 
However, Thai universities are increasingly adopting global citation indexes in their promotion procedures, thereby incorporating themselves into the English-language publication regime.

In contrast to Asia, Latin American universities have a long tradition of their own, based on Spanish and Portuguese, rather than English. They have in recent years largely adopted the publication regime; however, they permit greater scope to publications in those languages in their promotion procedures.

In Mexico, the Colegio de Postgraduados (2013) has introduced a points-scale for the appointment of academic staff. The higher the position in the academic hierarchy, the more exigent are the publication demands on the incumbent; thus, for the grade of Profesor Investigator Adjunto (Adjunct Research Professor) 30 points are stipulated for "publication of scientific articles, preferentially in journals with an editorial committee or of superior quality' (Colegio de Postgraduados 2013: 12, translation by authors), while for the higher grade of Profesor Investigator Asociado (Associated Research Professor) 40 points are stipulated for 'original research articles published in journals recognized on the international level (JCR)' and 30 points for 'original research articles published in journals recognized on the national level (CONACYT)' (Colegio de Postgraduados 2013: 19, translation by authors). Mexican universities thus recognize publications listed in the national language indexes in the assessment of their staff, but attach higher significance to those listed in international indexes.

In Brazil, the national research office, CAPES, produces the Qualis Classification List, which ranks the international and national scientific journals, in which Brazilian academics published their work, on an eight-grade scale, ranging from A1 to C; a journal may achieve different rankings on specific evaluation criteria (CAPES 2014), but its IF seems to be bestowed primacy in 
promotions, a tendency which has elicited some criticism (Brazilian Editors 2010). Within tourism studies, the highest ranking Qualis grade 'A1' was assigned only to Annals of Tourism Research, Tourism Geographies and Tourism Economics. A study has concluded that locally produced Brazilian tourism journals suffer from 'total lack of [global] visibility' due to their 'absence in national and international data bases' (Toledo Solha and Carmo Moreira Jacon 2010; translation by authors).

Most Brazilian universities use Qualis journal rankings in their promotion procedures. However, while publication in a Qualis A1 journal can put a Brazilian academic in an advantageous position, it is only one among several criteria, such as teaching and research project experience, in promotion and tenure decisions (Marcos Arnhold, personal communication, 14 August 2015).

In Turkish universities, especially those teaching in English, 'an increased emphasis on [academic] quality has been accompanied by the adoption of various assessment schemes, which have invariably attached top priority to the research and publication performance of their academic staff' (Şenses 2003: 1-2). The universities have hence imposed ever 'stricter criteria for academic appointment and promotions' (Şenses 2003: 2), and increasingly emphasized publications. The Turkish Higher Education Council compiles information from all universities on the publication performance of their staff, clearly distinguishing between domestic and international publications, and announces the results every year. The Council encourages international publications and takes the rise in their number as a strong sign of academic progress (Şenses 2003: 3). Regarding the role of publications in the promotion process, in 2000 'a new set of rules was introduced, requiring candidates [for an associate professorship] to accumulate a minimum number of total points from their publications...assigning highest points to international publications' (Şenses 2003: 3). Turkey's Academy of Science 'offers pecuniary rewards for international publications...published 
in SSCI journals ... [t]here is a long list of journals divided into several categories according to their impact levels.' The annual awards by the Academy are 'conditional on performance evaluated on the basis of the metric of international publications and citations' (Şenses 2003: 3).

In other Middle Eastern universities the criteria for promotion seem to be less rigorous. Thus at Zayed University in Al Ruwaiya, Dubai, 'scholarly research for promotion purposes...is traditionally measured by published writing. A solid record of scholarship can be evidenced by articles published in refereed journals respected in the field. The significance of a publication is often determined by the journal's acceptance rate and circulation,' an obvious proxy for journal ranking guides used by Western universities. The university also recognizes refereed conference papers published in conference proceedings, though these are not valued on the same level as refereed journal articles (University College. n.d.).

Our examples indicate that the dissemination of the Western publication regime does not constitute a mere 'best practices' or policies transfer, passively adopted by the universities in the emerging regions. Rather, under the hands of their leadership the process permutated and took on a life of its own. As some of our examples show, in some universities in the emerging regions metrified evaluation procedures underwent a level of specification and gained a degree of influence on academic life, which they rarely possess in leading Western universities: the fine tuning of the percentage contribution of multiple authors, the encouragement of internal competition between members of departments, the linkage of salaries with publication achievements, and the allocation of prizes for successful publication in high-ranking journals, which makes academics resemble prize-fighters. Moreover, as one of our reviewers indicated, the new evaluation procedures might in some instances become imbricated in university politics by a manipulation of promotion procedures, which the metrified techniques were meant to prevent. 


\section{The Emergence of Support Programs for Early Career Academics in the Emerging Regions}

The spread and permutation of the Western publication regime had an unintended side-effect: as a rising number of authors vie for placement in a small number of high-ranking international journals in their field, then the competition has intensified and chances of acceptance declined. Inundated by submissions from all around the world, leading journals were forced to reject an ever higher percentage of submissions. In fact, journal ranking guides, such as the ABS, define a 'top journal' (rated 4) as having 'high submission and low acceptance rates' (Association of Business Schools (ABS) 2015: 7). In tourism studies leading journals such as Annals of Tourism Research, Tourism Management, Journal of Travel Research and Journal of Sustainable Tourism are able to accept only a limited number of submissions. Early career staff in academic institutions in the emerging regions found themselves in a squeeze, resembling that faced by early career staff in the West: faced by growing pressure to fulfill their universities' new publication requirements, their chances of success declined as rejection rates of leading journals accelerated. Ill-prepared to live up to the demands placed upon them, they often felt frustrated and helpless.

The pressure to publish in highly ranked journals, often under a heavy teaching load (which frequently counts for little in promotion procedures), frequently without the necessary competencies, created the temptation for short-cuts among academic staff. This might take various forms: a preference for research methodologies which render fast results, such as the deployment of ready-made quantitative methods in the analysis of survey data, or, more recently, netnography (Kozinets 2002); the multiplication of authors of papers (Erlen, Siminoff, Sereika and Sutton 1997, Kovacs 2013), salami-slicing of study findings into several different papers (Abraham 2000), and in some instances, as we have seen above, even plagiarism. 
The need to improve the higher degree students' and early career staff's publication chances, by enhancing their writing skills, and disciplining their writings, thus gained growing attention (e.g. Cuthbert, Spark and Burke 2009). Articles began to appear on how to write manuscripts for successful publication (e.g. Benton 2014). Young researchers from the emerging regions increasingly attended Ph.D. programs in Western universities, where they were disciplined in Western academic writing standards, and advised on how to turn their theses into publications. Growing numbers of doctoral students and early career researchers turned up at international conferences, seminars and workshops to deliver papers as part of their efforts to gain international visibility.

Some universities have initiated special programs to help early career staff overcome their competitive disadvantages in the Western publication regime. Universities in Asia, for example, have engaged some senior, often retired, internationally recognized academics from Western countries, to mentor, supervise and guide early career staff, and sometimes even to jointly publish articles with them. In Southeast Asia, seminars, in which foreign researchers coached aspiring local staff in writing scientific papers, have been initiated by universities in Brunei, Malaysia, Indonesia and Thailand. Such seminars are less concerned with the subject matter of the early career staff's work, and more with the way of its presentation. In one such instance, two of the authors of this article were invited to a workshop organized in 2014 by the tourism department of a university in northern Thailand to guide and advise advanced students and early career staff members from several academic institutions in writing papers publishable in prestigious international journals in tourism studies. 
As we advised the participants in how to follow the requirements of the academic publication regime, we found that we were actually directing them to abandon culturally ingrained ways of thinking and writing, such as the tendency to conformism, avoidance of criticism, accompanied by a lack of emphasis on originality and hence a lack of desire to innovate. We also realized that in Thailand, as elsewhere in the emerging regions, much research on tourism continues to be funded by government with the formal expectation that it will assist in development programs and policymaking and evaluation, and therefore requires a more practical, report-type approach to writing, which is often unsuitable for international publications. We had to reorient the participants' writings away from that tendency, toward the requirements of the Western publication regime, such as the adoption of a broad, theoretical approach (see Shamsul, 2007; Yamashita, Bosco and Eades, 2004) and the presentation of innovative conclusions.

We found the experience of disciplining the writing of early career staff rather ambiguous. While dispensing our advice seemed justified for the purposes at hand, we left with the impression that our disciplining efforts had a neo-colonial flavor: two Westerners advising local academic staff how to adapt to (and adopt) the prescriptions of a Western-centered publication regime. We realized that beneath the disciplining process lurk some complex political, ethical and epistemological issues, which have been largely disregarded in the literature and by the administrations of universities in the emerging regions, in their rush to improve the global rankings of their institutions. This realization led us to consider some broader implications of the process in which universities in emerging regions are drawn into the Western publication system. 


\section{Neo-colonial implications of the dissemination of the Western publication regime}

The adoption of the Western publication regime by universities in the emerging regions often engendered tensions, anxiety and frustration among staff members, who faced difficulties in living up to the demands of the regime, leading in some instances to plagiarism and the faking of data (Economist 2013). Universities in the emerging regions have introduced some ameliorating mechanisms, intended to discipline the academic writing of early career staff, to reduce the tensions and to facilitate the acceptance of the work of early career staff in prestigious journals. These mechanisms may be interpreted as a means to resolve a 'functional' discrepancy between the demands of the adopted regime, and the ability of the academic staff in the emerging regions to live up to them. However, while such mechanisms might appear to be politically 'innocent,' our experiences indicated that the efforts to discipline the writing of local academics conceal a neocolonial aspect inherent in the process of dissemination of the publication regime: we realized that the imposition of Western academic writing standards tends implicitly to suppress and devalue local intellectual traditions. This raises some fundamental intellectual and ethical issues, which have remained largely unnoticed by the local promoters of the adoption of the publication regime, but which link directly with the post-colonial criticism of Western intellectual domination expressed by some Asian academics in the past.

Thus, several Southeast Asian intellectuals, based mainly in the National University of Singapore, have criticized the dominance of Western academics in determining research priorities, interests and agendas in Asian academic institutions. A leading critic, Syed Farid Alatas (2006), argued against external academic dominance and for an alternative, autonomous Asian scientific discourse, based on local experiences, priorities, interests and knowledge. More recently, Goh 
Beng Lan, from the Department of Southeast Asian Studies, called for an engagement with an alleged 'Western' or 'Euro-American hegemony' of knowledge-generation on Southeast Asia, whilst advocating 'the creation of locally relevant methodologies and knowledge' (2014: 41; see also Goh 2011). Goh (2014: 28) recognizes that 'while history, meanings and analytical categories in Asian societies may originate from and are inevitably interconnected to the West, a comparative study of their particular unfolding across different Asian contexts may help scholars capture analytical registers, social categories and meanings that depart from Western ones'. Chua Beng Huat, Provost's Chair Professor in Sociology, also acknowledged that some members of Southeast Asian academia continue to contest 'Euro-American epistemological domination through different conceptualizations of the East-West difference, for example by a critique of Western cultural imperialism and orientalism, by provincializing the West...and/or pointing out alternative modernities'. However, he argues that Asian scholars should not seek to excise Western paradigms, concepts and approaches but they should rather 'multiply their points of reference within Asia and treat them as equal to Europe and America' (2014: 273-274).

Two Indian marketing researchers at the prestigious Indian Institute of Management, Varman and Saha (2009), insightfully discussed the dilemma involved in the adoption of a Eurocentric epistemological paradigm by Asian academics. Combining Foucault's (1977) claim, that the object of a disciplinary process is to produce docile subjects, with post-colonial theory, they observed that, 'Eurocentric prescriptions in India have played an important role in [the] process of disciplining [of academic writing]' (Varman and Saha 2009: 813). Referring to their own subject these authors argued that, owing to this disciplining process, the 'marketing discipline in the Third World is made into an appendage of the Western knowledge system' (Varman and Saha 2009: 813). Reflecting on their own role, the authors asserted that 'as researchers in a business school in 
the Third World, we are both victims and perpetrators of the very epistemic ideology we have chosen to critique in [our own] research' (Varman and Saha 2009: 815). That research had shown that 'doctoral researchers [in top ranked Indian business schools] emulate the research agenda developed in the West to avoid internal resistance to their works and to instrumentally access journals for publishing in the First World' (Varman and Saha 2009: 821). Varman and Saha thus perceive the very striving of these doctoral candidates to live up to the demands of the publication regime as virtually an ethical failure. A similar argument could be raised with regard to the field of tourism studies, because there is little doubt that the same processes identified by Varman and Saha are present in this field as well. Our own contribution to the disciplining of the writings of early career academic staff thus unintentionally constituted another means of promulgation of a neo-colonial Western academic hegemony.

\section{Discussion}

In this article we used the example of tourism studies to illustrate the process of dissemination and gradual permutation of the Western publication regime into the emerging regions of the world. It is important to point out that in most universities in those regions, appointments and promotions in tourism departments or schools are dominated by state-wide or university-wide procedures, while only prominent schools enjoy a degree of autonomy in their appointment and promotion procedures. The field of tourism studies thus reflects the general trends of change taking place in the institutions of higher learning in the emerging regions of the world.

Our presentation leads to several significant, mutually interconnected points:

1) We have introduced the concept of the 'publication regime' in order to articulate the current interlocking of the domination of publication of academic journals by a few giant publishing 
conglomerates, with the deployment of metrified journal rankings for appointment and promotion procedures in institutions of higher learning. We consider the Editors-in-Chief of those journals, who are usually academics, but are employed by the publishing conglomerate, to constitute the axis connecting the two domains.

2) The publication regime was first introduced by some Western countries, particularly the U.K., Australia and New Zealand, in the wake of the adoption of neo-liberal management policies in the administration of Western universities, according to which scientific production is measured as a pay-off for public investments in universities, just as profit is measured as a pay-off for private financial investments in business establishments. We showed that, notwithstanding the growing criticism of the metrification of scientific production in the contemporary West, this regime has been increasingly adopted by the institutions of higher learning in the emerging regions of the world. This indicates that the publication regime is becoming increasingly globalized. But the regime was not just passively adopted. Rather in the process of its global adoption it also underwent permutations, which increasingly differentiate its application in the emerging regions from that in the West.

3) Though neo-liberal policies were introduced in the management of some universities in the emerging regions, their growing adoption of the publication regime appears to be primarily motivated by considerations of prestige, as indicated by their standing in global university rankings. Academia has thus increasingly come to resemble professional competitive sports practiced on the global level (Şenses 2013). The resemblance has grown as in some countries, such as China (Shao and Shen 2011) and Turkey (Şenses 2003), where pecuniary rewards are offered for publications in high-ranking journals, resembling prizes awarded to sporting professionals. This process of globalization, however, is marked by a paradox: even as the 
wave of its uncritical adoption spreads in the emerging regions, the publication regime is undergoing growing criticism in Western countries as an inadequate measurement of the quality of academic achievement (e.g. Tadajewski 2016).

4) The globalization of the publication regime is not proceeding in a uniform rhythm. There are major differences between the emerging regions, and countries within them, in the degree to which the universities adopted the regime. The adoption appears to be more intensive and strict in leading research universities, particularly in Asia, which are applying in their evaluations of candidates more demanding criteria, particularly metrified rankings of the journals in which they have published. The adoption of the regime is more lax in less prestigious institutions of higher learning, particularly in academically peripheral regions, such as the Middle East and Africa, which tend primarily to base their evaluations of candidates on general criteria, such as publication in refereed journals or in journals included in international indexes, and less on metrified criteria.

5) The rigor of the adaptation of the publication regime by universities in the emerging regions has been modified by a process of 'glocalization': the recognition of publications in local outlets, which are not included in the major international indexes (and not published by the leading publishing houses). Such works are often published in the national language. The emergence of national publications indexes has facilitated that practice. However, universities in the emerging region continue to allot a greater weight to publications in internationally indexed outlets.

6) The discrepancy between the aspirations of the universities in the regions for enhanced rankings and actual academic achievements of their academic staff led to the introduction of auxiliary mechanisms to discipline and enable the staff to live up to the demands of the 
publication regime. These efforts have taken various specific forms, but generally involved the engagement of Western academics as tutors of the local staff. While the introduction of these auxiliary mechanisms appears to have been motivated by innocent professional considerations, the disciplining process bears some implicit neo-colonial traits, in that it imposes upon the local staff the principles of academic writing prevailing in Western universities (and demanded by the publication regime), which might run contrary to local cultural and intellectual traditions.

7) The globalization of the academic publication regime thus involves a dilemma: how to foster intellectual pluralism in scientific work, which would ameliorate uncritical Western domination of the regime and bestow academics of the emerging regions with fair access to publication in prestigious periodicals, while preserving the unity of the scientific enterprise. But rather than Alatas' radical advocacy of an epistemological dualism (cf. Cohen and Cohen 2015), the position adopted by Goh Beng Lan $(2011,2014)$ and Chua Beng Huat (2014), who advocate a continuing connection with Western intellectual traditions, while advocating their modification, adaptation and contextualization in relation to Asian traditions, appears a less divisive way towards the resolution of this issue. Their approach might provide opportunities for the integration of non-Western perspectives into the framework of the publication regime, as for example by the recognition of learned dissertations on religious or philosophical topics by Asian intellectuals, which are not presented in accordance with the normalized procedures of the publication regime, as worthy of publication. However, the present rather uncritical adoption by the universities in the emerging regions of the Western publication regime lowers the chances of such an adaptation in the near future. 


\section{Conclusion}

In concluding this critical paper, we would like to make three broader observations. One, there is a certain irony implicit in the progressive globalization of the publication regime. The regime certainly projects a readiness to include academics from the emerging regions into its ranks, and some of its representatives indeed work to facilitate that inclusion. But the inclusion is predicated on accepting the regulatory premises of the regime, thereby silencing the voices of those who seek to participate on alternative premises, based on local intellectual traditions.

Two, paradoxically, while the universities in the emerging regions tend to stick mechanically to the metrified techniques of evaluation of scientific excellence, developed in the West, there are indications that those techniques might be bent or 'glocalized' to serve the academic infighting which pervades many institutions of higher learning throughout the emerging regions.

Finally, the widespread adoption of the publication regime by universities in the emerging regions, often purely for reasons of gaining international prestige, might have some wider problematic implications for their scientific development in the long range: the emphasis on publication in leading journals of articles which will generate numerous citations, might not be the best policy for nurturing scientists who make important and creative contributions to scientific advancement. Such policies de-emphasize intellectual speculation and creativity, while discouraging specialization in sub-fields where major contributions may be recognizable by only a small number of specialists, as is the case, for example, in some complex branches of mathematics. The present thirst for prestige might thus stand in the way of the contribution of academics from the emerging regions to fundamental processes of scientific progress. 
Acknowledgements. Thanks are due to Bob McKercher, Carlos Monterrubio, Ismar Borg de Lima, Joan Henderson, Shanthi Thambiah, Xuan Zhu, and Marcos Arnhold for the supply of information for this article.

\section{References}

Abraham, P. 2000. Duplicate and salami publications. Journal of Postgraduate Medicine. 46(2), 67-69.

Abrahamsen, R. 2000. Disciplining democracy: development discourse and good governance in Africa. London: Zed Books.

Airey, D., Tribe, J., Benckendorff, P. and Xiao, H. 2015. The managerial gaze: The long tail of tourism education and research. Journal of Travel Research, 54(2), 139-151.

Association of Business Schools (ABS) 2015. Academic Journal Guide 2015, accessed 1 April 2015, http://www.bizschooljournals.com/

Alatas, S.F. 2006, Alternative Discourses in Asian Social Sciences: Responses to Eurocentrism, New Delhi: Sage.

Altbach, P.G. 2004. Globalization and the university: Myths and realities in an unequal world. Tertiary Education and Management 10(1): 3-25.

Benton, M.J. 2014. Dissemination of evidence: writing research manuscripts for successful publication. Clinical Nurse Specialist 28(3): 138-140.

Bill, A. 2004. Disciplining creativity: neo-liberalism and design education in New Zealand. Proceedings of the Design Research Societies International Conference. Melbourne: Future Ground.

Brazilian Editors 2010. Classification of journals in the QUALIS system of CAPEs - Urgent need of changing the criteria! Clinics [Sao Paulo] 65(2): 121-123.

Butler, N. and Spoelstra, S. 2014. The regime of excellence and the erosion of ethos in critical management studies. British Journal of Management 25: 538-550.

CAPES 2014. Classificação da produção intellectual. 1 April http://www. capes.gov.br/avaliacao/instrumentos-de-apoio/classificacao-da-productos-intelectiual

Chua B. H. 2014. Inter-referencing Southeast Asia: Absence, Resonance and Provocation', in Hutari, M., Rüland, J. and Schlehe, J,. eds, Methodology and Research Practice in Southeast Asian Studies, Houndmills, Basingstoke and New York: Palgrave Macmillan, pp. 273-288. 
Cohen, E. and Cohen, S.A. 2015. Beyond Eurocentrism in tourism: a paradigm shift to mobilities. Tourism Recreation Research, 40(2): 157-168.

Colegio de postgraduados 2013. Reglamento de promocionesacadémicas [Mexico].

Cuthbert, D., Spark, C. and Burke, E. 2009. Disciplining writing: The case for multi-disciplinary writing groups to support writing for publication for higher degree by research candidates in the humanities, arts and social sciences. Higher Education Research and Development 28(2): 137149.

Dunn-Kenney, M. 2013. Disciplining the teacher: the disembodied professional and the decline of vernacular wisdom in teacher education. The International Journal of Illich Studies 3(1): 44-56.

Economist 2013. Looks good on paper. 28 September

Erlen, J.A., Siminoff, L.A., Sereika, S.M. and Sutton, L.B. 1997. Multiple authorship: Issues and recommendations. Journal of Professional Nursing 13(4): 262-270.

Espeland, W.N., and Sauder, M. 2007. Rankings and reactivity: How public measures recreate social worlds. American Journal of Sociology 113(1): 1-40.

Foote, C. and Frank. A 1999. Foucault and therapy: The disciplining of grief. In Chambon, A., Irwing, A. and Epstein, L. eds. Reading Foucault for social work. New York: Columbia University Press, pp. 157-187.

Foucault, M. 1977. Discipline and punish: The birth of the prison. London: Allen Lane.

Glick Schiller, N. and Salazar N.B. 2013. Regimes of mobilities across the globe. Journal of Ethnic and Migration Studies 39(2): 183-200.

Goh B. L. 2011. Decentering and Diversifying Southeast Asian Studies: Perspectives from the Region, Singapore: ISEAS Press.

Goh B. L., 2014. 'Moving Theory and Methods in Southeast Asian Studies', in Hutari, M., Rüland, J. and Schlehe, J,. eds, Methodology and Research Practice in Southeast Asian Studies, Houndmills, Basingstoke and New York: Palgrave Macmillan,,pp. 27-43.

González, C., Liu, J. and Shu, X. 2012. The faculty promotion and merit system in China and the United States: The cases of Wuhan University and the University of California, Davis. Research and Occasional Paper Series: CSHE 13.12. Center for Studies in Higher Education, University of California, Berkeley.

Grant, B. 1997. Disciplining students: the construction of student subjectivities. British Journal of Sociology of Education 18(1): 101-114. 
Hall, C.M. 2013. Framing tourism geography: Notes from the underground. Annals of Tourism Research 43: 601-623.

Hall, C.M. and Page, S.J. 2015. Following the impact factor: Utilitarianism or academic compliance? Tourism Management, 51, 309-312.

Hussain, S. 2013. Journal list fetishism and the 'sign of 4' in the ABS guide: A question of trust? Organization, 22(1): 119-138.

Knights. D. and Collinson, D. 1987. Disciplining the shopfloor: a comparison of the disciplinary effects of managerial psychology and financial accounting. Accounting, Organization and Society 12(5): 457-477.

Kosinets, R.V. 2002. The field behind the screen: Using netnography for marketing research in online communities, Journal of Marketing Research 39(1): 61-72.

Kovacs, J. 2013. Honorary authorship epidemic in scholarly publications? How the current use of citation-based evaluative metrics make (pseudo)honorary authors from honest contributors of every multi-author article. Journal of Medical Ethics 39: 509-512.

Lao, R. 2015, A critical study of Thailand's higher education reforms. New York: Routledge.

McKercher, B. 2015. Why and where to publish. Tourism Management, 51, 306-308.

Middleton, S. 2005. Disciplining the subject: the impact of PBRF on education academics. New Zealand Journal of Educational Studies 40(1/2): 131-155.

Morris. D., Yaacob, A. and Wood, G. 2004. Attitudes towards pay and promotion in the Malaysian higher educational sector. Employee Relations 26(2): 137-150.

Niesche, R. 2013. Foucault and educational leadership: disciplining the principal. London: Routledge.

Perdue, R.R. 2015. The unintended consequences of impact factors on tourism research: Thoughts and comments. Tourism Management, 51: 303-305.

Poocharoen, O-o. and Brillantes, A. 2013. Meritocracy in Asia Pacific: Status, issues, and challenges. Review of Public Personnel Administration 33(2): 140-163.

Poria, Y., Schwartz, Z. and Uysal, M. 2015. If you can keep your head: The unintended consequences of the Impact Factor on tourism research. Tourism Management, 51: 300-302.

Şenses, F. 2003. Difficulties and trade-offs in performance evaluation in social sciences: A Turkish perspective. Ankara: Middle East Technical University, Economic Research Center, ERC Working Papers in Economics 03/11. 
Shao, J. and Shen, H. 2011. The outflow of academic papers from China: why is it happening and how can it be stemmed? Learned Publishing 24(2): 95-97.

Shamsul, A.B. 2007. Producing Knowledge of Southeast Asia: a Malaysian View. In Chen, K.H.and Chua Beng Huat, eds. The Inter-Asia Cultural Studies Reader. Abingdon, Oxford and New York: Routledge, 2007, pp. 140-160

Smeyers, P. and Burbules, N.C. 2011. How to improve your impact factor: Questioning the Quantification of academic quality. Journal of Philosophy of Education 45(1): 1-17.

Tadajewski, M. 2016. Academic labour, journal ranking lists and the politics of knowledge production in marketing. Journal of Marketing Management 32(1-2): 1-18.

Toledo Solha, K. and Carmo Moreira Jacon, M. 2010. Evaluación de revistas electrónicas brasileñas de turismo. Estudios y Perspectivas en Turismo 19(2): 182-200.

Torres, C.A. and Schugurensky, D. 2002. The political economy of higher education in the era of neoliberal globalization: Latin America in comparative perspective. Higher Education 43(4): 429455.

Universities Grant Commission 2010. UGC regulations for appointment of teachers and other academic staff in universities and colleges and measures for the maintenance of standards in higher education. Gazette of India 18 September: 7948-7996.

University College n.d. Zayed University, Ruwaiya [Dubai], UAE.

Vanclay, J.K. 2012. Impact Factor: Outdated artifact or stepping -stone to journal certification? Scientometrics 92(2): 211-238.

Varma, I.M. 2015. Impact, not impact factor. Proceedings of the National Academy of Sciences 112(26): 7875-7876.

Varman, R. and Saha, B. 2009. Disciplining the discipline: Understanding postcolonial epistemic ideology in marketing. Journal of Marketing Management. 25(7-8): 811-824.

Yamashita, S., Bosco, J and Eades, J.S. 2004 Asian Anthropologies: Foreign, Native, and Indigenous. .In Yamashita, S., Bosco, J. and Eades, J.S., eds, The Making of Anthropology in East and Southeast Asia. New York and Oxford: Berghahn Books, 2004, pp. 1-34. 